\title{
EVALUASI MITIGASI STRUKTUR BENCANA GEMPA BUMI DI WILAYAH PULAU DOOM KOTA SORONG
}

\author{
Meikel Bawoleh ${ }^{1)}$, Wennie Mandela ${ }^{2)}$, Achmad Rusdi ${ }^{2)}$ \\ 1) Mahasiswa Program Studi Teknik Sipil Universitas Muhammadiyah Sorong \\ 2) Dosen Program Studi Teknik Sipil Universitas Muhammadiyah Sorong
}

\begin{abstract}
ABSTRAK
Pasca kejadian gempa yang menggoncang Kota Sorong tidak sedikit bangunan rumah tinggal di Pulau Doom mengalami kerusakan. Oleh karena itu, perlu adanya evaluasi kelayakan struktur terhadap bangunan rumah tinggal masyarakat untuk mengantisipasi kerusakan yang mungkin terjadi apabila terjadi gempa berikutnya. Upaya mitigasi bencana perlu dilakukan secara menyeluruh, efektif dan efisien dalam rangka mengurangi resiko akibat gempa.

Evaluasi mitigasi bencana gempa struktur di Pulau Doom dimaksudkan untuk mengamati secara langsung apakah rumah-rumah warga telah memenuhi ketentuan-ketentuan untuk rumah tahan gempa. Survei yang dilakukan dengan menggunakan format formulir evaluasi bangunan sederhana (tipikal tembokan), diadopsi dari FEMA yang telah dimodifikasi oleh Imam Satyarno (Satyarno, 2012) yang di dalamnya telah disesuaikan dengan kondisi bangunan di Indonesia, di mana sebagai acuan untuk mempertimbangkan kondisi bangunan yang ada di wilayah Pualu Doom.

Hasil dari evaluasi mitigasi untuk bangunan rumah tinggal pada Pulau Doom dapat dikatakan bahwa hampir semua belum memenuhi persyaratan yang telah ditentukan dalam persyaratan teknis bangunan tahan gempa. Hal ini menunjukan kesadaran akan pentingnya membangun suatu struktur bangunan tahan gempa belum sungguh-sungguh dipahami oleh masyarakat di Pulau Doom. Sehingga ini biasa menyebabkan tingkat resiko kerusakan dan hilangnya korban jiwa pada saat terjadinya gempa menjadi lebih besar dan hal tersebut perlu penangan serius.
\end{abstract}

Kata kunci : Mitigasi, Rumah Tahan Gempa, Evaluasi Bangunan sederhana

\section{PENDAHULUAN \\ Latar Belakang}

Secara geologis Indonesia terletak pada tiga lempeng besar dan memiliki banyak gunung berapi. Indonesia merupakan negara yang rentan terhadap bencana baik geografis maupun meteorologi, dari aspek tenaga tektonik Indonesia bagian timur memiliki potensi ancaman bencana gempa bumi dua kali lipat dibanding dengan Indonesia bagian barat.

Kota Sorong merupakan salah satu wilayah di Indonesia yang sering mengalami bencana gempa, Gempa bumi cukup besar yang menimpa Kota Sorong terjadi pada tanggal 24 September 2015 pada pukul 22.53 WIB yang berkekuatan 6,8 SR dengan kedalaman gempa bumi 10 kilometer yang berpusat di laut berjarak 31 kilometer Timur Laut Kota Sorong, Papua Barat (DetikNews). Pasca kejadian tersebut bangunan rumah tinggal di kota Sorong banyak yang mengalami kerusakan, tak terkecuali Pulau Doom atau yang biasa disebut juga pulau Dum oleh masyarakat asli setempat (suku Malamooi). Pulau
Doom merupakan pulau besar yang terletak diluar kota Sorong dengan penghuni yang cukup padat, tercatat jumlah penduduk pada tahun 2009 adalah sebesar 12.388 jiwa dan 2.546 kepala keluarga (Tanzil, 2014).

Pada saat bencana gempa bumi terjadi bukan hanya kerusakan bangunan saja yang dialami namun korban jiwapun cukup banyak berjatuhan. Oleh karena itu evalusai terhadap struktur bangunanpun dianggap sangat penting mengingat selama ini evalusai struktur bangunan biasanya dilakukan setelah terjadi bencana gempa bumi. Dalam upaya mitigasi untuk meminimalisasi resiko dari bencana gempa bumi maka perlu adanya evalusai struktur bangunan, namun evaluasi struktur tersebut sangat jarang dilakukan.

Upaya mitigasi bencana gempa bumi tidak hanya mempelajari tentang sejarah kegempaan, namun juga harus memahami secara benar mengenai kerentanan dan kondisi tanah maupun struktur bangunan terhadap gempa bumi. Mitigasi merupakan serangkaian upayah untuk 


\section{Jurnal Rancang Bangun 2(2)37-44 2017}

mengurangi resiko bencana baik melalui pembangunan fisik dan non fisik seperti penyadaran dan peningkatan kemampuan masyarakat dalam menghadapi ancaman bencana. Pembanguanan fisik meliputi tata bangunan, pengaturan pembanguanan, pembangunan infrastruktur dan pelaksanaan infrastruktur (UU No.24 Tahun 2007).

\section{Tujuan Penelitian}

Adapun tujuan dari penelitian ini adalah untuk mengetahui apakah struktur bangunan di wilayah kepulauan Kota Sorong yaitu pulau Doom telah memenuhi standar bangunan tahan gempa menurut evaluasi bangunan sederhana (tipikal tembokan), yang diadopsi dari FEMA (Federal Emergency Management Agency) yang telah dimodifikasi oleh Iman Satyarno (Satyarno, 2012) yang di dalamnya telah disesuaikan dengan kondisi bangunan di Indonesia.

\section{METODOLOGI PENELITIAN}

Penelitian ini secara umum dilaksanakan pada wilayah kepulauan Kota Sorong, yaitu berlokasi di pulau Doom.

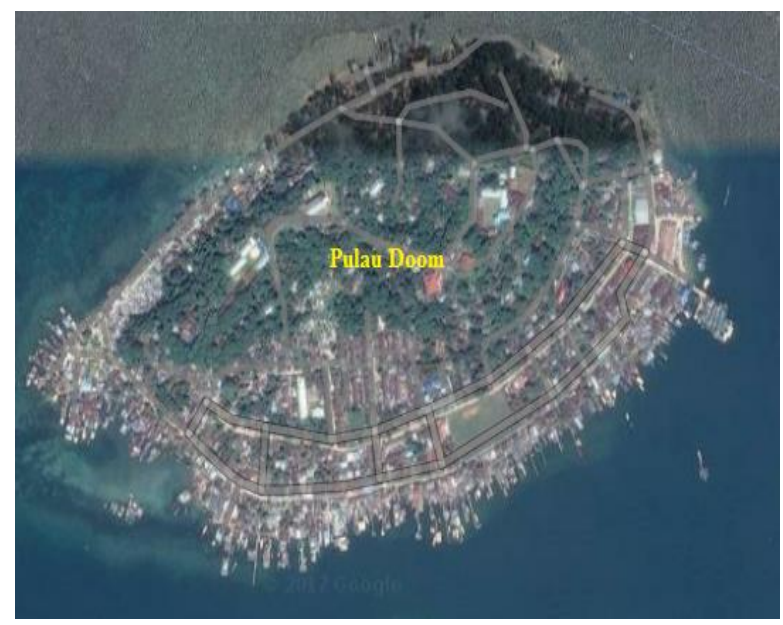

Gambar 1. Lokasi Penelitian

\section{Tahapan Penelitian}

1. Tahap Persiapan

Pada tahap persiapan ini meliputi :

a. Studi pustaka terhadap materi untuk proses analisa

b. Menemukan kebutuhan data

c. Mendata instansi dan institusi yang dapat dijadikan sumber data.

2. Tahap Pengumpulan Data

Pengumpulan data merupakan langkah awal setelah tahap persiapan dalam proses pelaksanaan yang sangat penting, karena dapat ditentukan permasalahan dan rangkaian penetuan alternatif pemecahan masalah yang akan diambil. Adapun beberapa metode yang dilakukan dalam tahap pengumpulan data ini antara lain :

a. Data Primer

Data primer adalah data yang langsung diambil dari lapangan, meliputi : observasi, wawancara, diskusi terfokus serta penyebaran kuesioner seperti di bawah ini. 


\section{Jurnal Rancang Bangun 2(2)37-44 2017}

\section{FORMULIR EVALUASI BANGUNAN SEDERHANA CTIPIKAL TEMBOKANM}

\begin{tabular}{|c|c|}
\hline \multicolumn{2}{|l|}{ Alamat pernilik } \\
\hline $\begin{array}{l}\text { Prophnsi } \\
\text { Whayahikab. }\end{array}$ & 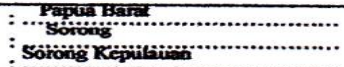 \\
\hline $\begin{array}{l}\text { Kelurahan/ deaga } \\
\text { Nama KK } \\
\text { Alamat }\end{array}$ & : \\
\hline
\end{tabular}

\begin{tabular}{|c|c|c|}
\hline $\begin{array}{l}\text { Pernbuatan } \\
\text { Ukuran Rumah }\end{array}$ & $\begin{array}{l}\text { DDengen perenceane } \\
\text { Parjeng : }\end{array}$ & $\begin{array}{c}\text { DTanpa perencana } \\
\text { Leber : ............ m }\end{array}$ \\
\hline $\begin{array}{l}\text { Perakhan Tulangan } \\
\text { Pembuatan Beton }\end{array}$ & $\begin{array}{l}\text { DMarual } \\
\text { CManual }\end{array}$ & $\begin{array}{l}\text { aMesin } \\
\text { aReady Mix }\end{array}$ \\
\hline
\end{tabular}

Petunjuk Pengisian : Beri tanda (V) pada kotak yang sesuai
NO PENOAMATAN

\begin{tabular}{|c|c|c|c|c|c|}
\hline NO & & PENGAMATAN & YA & TIDAK & KURANG \\
\hline A & GAMBAR RENCANA & 1. Pembangunan berdasarkan gamber rencana & ㅁ & ㅁ & \\
\hline \multirow{2}{*}{ B } & DENay & 2. Denah simetris & 口 & 무 & \\
\hline & & 3. Thdak ada tonjolan $>25 \%$ dari ukuran denah terbesar & 口 & 口 & \\
\hline \multirow{5}{*}{ c } & \multirow{5}{*}{ PONDASI } & 4. Kodalaman sesual manuel perancanpen $(\mathrm{mln} .60 \mathrm{~cm})$ & 무 & 무 & \\
\hline & & 5. Lobar sesulal manual perancengen $(\mathrm{min} .60 \mathrm{~cm})$ & 口 & 므 & \\
\hline & & 6. Tulangan kolom ditanamikan dolam pondasi sedalam 40 b atau lebih & 므 & 므 & \\
\hline & & 7. Batu kell keras atren beptu putin keres & 무 & 무 & \\
\hline & & 8. Campuran mortar untuk spesil I pc: 4 por & 무 & 무 & \\
\hline \multirow{6}{*}{ D } & \multirow{6}{*}{ SLOOF } & 9. Ukuran minimal sesual manutal perancancan $(\mathrm{mln} .15 \mathrm{~cm} \times 20 \mathrm{~cm})$ & 무 & 므 & \\
\hline & & 10. Tulangan memanjang sosual manuel perancangan (min 4\% 10) & 므 & 므 & \\
\hline & & 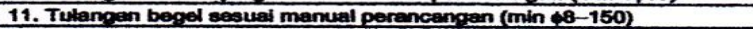 & 무 & 무 & \\
\hline & & 12. Ada an okar ke fondeal & D & 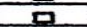 & \\
\hline & & 13. Apalcah beton sloof bell (tidak keropos) & ㅁ & 문 & \\
\hline & & 14. Campuran beton $1 \mathrm{pc}: 2 \mathrm{psr}: 3 \mathrm{~kg}$ & 무 & $\square$ & \\
\hline \multirow{5}{*}{$\mathbf{E}$} & \multirow{5}{*}{ Kolom } & 15. Ukuren minhmel sosual manual perancengan $(\mathrm{min} .15 \mathrm{~cm} \times 15 \mathrm{~cm})$ & 무 & 口 & \\
\hline & & 16. Tulangan memanjang sesual manual perancangan $(\min 410)$ & $\square$ & $\square$ & \\
\hline & & 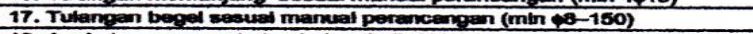 & 무 & 口 & \\
\hline & & 18. Apakah campuran beton kolom balk (Gidak kercopos) & $\square$ & $\square$ & \\
\hline & & 19. Campuran betion 1 pe: $: 2$ per : $3 \mathrm{kt}$ & $\square$ & $\square$ & \\
\hline \multirow{3}{*}{$\mathbf{F}$} & \multirow{3}{*}{ DANDANG } & 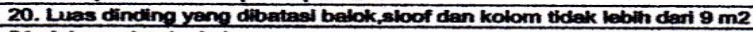 & $\square$ & 무 & \\
\hline & & 21. Ada angkur ke kolom & 口 & ㅁ & \\
\hline & & 22. Campuran mortar untulk spesed 1 pc : 4 par & 므 & 므 & \\
\hline \multirow{5}{*}{$\mathbf{6}$} & \multirow{5}{*}{ RANG BALK } & 23. Ukuran minimal sesual manual perancangan $(\mathrm{min} .12 \mathrm{~cm} \times 15 \mathrm{~cm})$ & ㅁ. & 무 & \\
\hline & & 24. Tulangan memanjang sosual manual perancangan $(\min 4+10)$ & 모 & 묘 & \\
\hline & & 25. Tulangen begel sesuel manual perancangan $(\min \varphi \theta-150)$ & 문 & $\square$ & \\
\hline & & 26. Apakah campuran beton ning belik belk (kctak keropoes) & 口 & 모 & \\
\hline & & 27. Campuran boton $1 \mathrm{pc}: 2 \mathrm{psr}: 3 \mathrm{~kg}$ & 문 & $\square$ & \\
\hline H & $\begin{array}{l}\text { DETAR TULANGAN } \\
\text { PADA PERTEMUAN } \\
\text { UUUNG BALOK DAN } \\
\text { KOLOM }\end{array}$ & $\begin{array}{l}\text { 28. Tutangan pede sudut akchir diangkur dengen panjang } 40, \text { atau } 304 \\
\text { dengan kest. }\end{array}$ & $\square$ & 口 & \\
\hline I & SAMBUNGAN & 20. Ade ovorlap (combungen lomplen) min 404 & D & 口 & \\
\hline \multirow{6}{*}{ J } & \multirow{6}{*}{$\begin{array}{l}\text { GUNUNG-GUNUNG } \\
\text { (dari beton) }\end{array}$} & 30. Ada angkur untuk gording & 무 & ㅁ & \\
\hline & & 31. Apelkah campuran beton belok miring belk (tidak koropos) & 口 & 무 & \\
\hline & & 32. Uikuran minimel sesual menual perancangen $(\mathrm{min} .12 \mathrm{~cm} \times 15 \mathrm{~cm})$ & 무 & ㅁ & \\
\hline & & 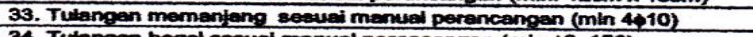 & 口 & 口 & \\
\hline & & 34. Tutangen bogol soevial momial perencengen $(\min 4 \mathrm{Q}-150)$ & 문 & & \\
\hline & & 35. Ada llcotan angin & 口 & 문 & \\
\hline \multirow{5}{*}{$\mathbf{K}$} & \multirow{5}{*}{$\begin{array}{l}\text { KuDA-KUDA } \\
\text { (dan kayu) }\end{array}$} & 36. Ukuran kayu minimal $6 \mathrm{~cm} \times 12 \mathrm{~cm}$ & 口 & & \\
\hline & & 37. Sembungan diberd plat begel & $\square$ & 口 & \\
\hline & & 38. Ade iketan angin. & 口 & $\square$ & \\
\hline & & 39. Ade angkeur peda duchutcarnirye & 무 & 口 & \\
\hline & & 40. Kayu berwame gelap & 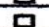 & 口 & \\
\hline
\end{tabular}

Pada kolom kurang dapat dilsi vdan keterangan jika kondisinya ada tetapi kurang dari persyaratan minimum. Jika tidak tahu berarti "TIDAK"

Jumiah jawaban "YA-

Jumlah lavraban "KURANG"

Jumlah nilai

$=\ldots \ldots+5 \times 0.5=\ldots$

Skor Bangunan = jumlah nilai/40 x $100 \%=$

Catatan: jika suatu rumah tidak mempunyai gunung-gunung atau kuda-kuda maka Jumlah penyebut di atas tidak 40 tetapi disesuaikan dengan jumlah total pertanyaan yang dapat diisi

\begin{tabular}{|l|l|l|}
\hline \multicolumn{1}{|c|}{ Velidasi } & Pemlink'pembuat numah & Polaksana Evaluaes \\
\hline NamaLentap & & \\
\hline Tanda Tangan & & \\
\hline Tgl: & & \\
\hline
\end{tabular}

Tabel 1. Formulir Evaluasi Bangunan Sederhana (Tipikal Tembokan)

b. Data Sekunder

Data sekunder adalah data yang diperoleh atau dikumpulkan peneliti dari berbagai sumber yang telah ada (peneliti sebagai tangan kedua). Data sekunder dapat diperoleh dari berbagai sumber seperti Biro Pusat Statistik (BPS), buku, laporan, jurnal, dan lainlain.

\section{- Teknik Pengambilan Data}

Data didapatkan dengan melakukan survei di pulau Doom, di mana peneliti secara langsung melihat, mengamati, serta mengevaluasi mitigasi bencana gempa struktur pada wilayah tersebut. Dari penelitian ini, maka peneliti juga akan melihat apakah di sepanjang wilayah pulau Doom telah memenuhi ketentuan-ketentuan untuk rumah bangunan tahan gempa. Survei yang dilakukan 


\section{Jurnal Rancang Bangun 2(2)37-44 2017}

dengan menggunakan format formulir evaluasi bangunan sederhana (tipikal tembokan), diadopsi dari FEMA yang telah dimodifikasi oleh Imam Satyarno (Satyarno, 2012) yang di dalamnya telah disesuaikan dengan kondisi bangunan di Indonesia, di mana sebagai acuan untuk mempertimbangkan kondisi bangunan yang ada di wilayah pulau Doom. Dari data tersebut, maka peneliti dapat mengevaluasi bagaimana mitigasi bencana gempa stuktural.

\section{HASIL PENELITIAN DAN PEMBAHASAN}

Hasil Evaluasi Bangunan Sederhana untuk Bangunan Tahan Gempa pada Pulau Doom.

Tabel 2. Hasil Evaluasi Bangunan Sederhana (Tipikal Tembokan) Di Salah Satu Rumah Warga Pulau Doom

\begin{tabular}{|ll|}
\hline Alamat pemilik & \\
\hline Propinsi & : PAPUA BARAT \\
Wilayah/Kab. & : KOTA SORONG \\
Kecamatan & : SORONG KEPULAUAN \\
Kelurahan/ desa & : DOOM TIMUR \\
Nama KK & : BAREN M \\
Alamat & : RT 01-RW 01 \\
\hline
\end{tabular}

\begin{tabular}{|c|c|}
\hline \multicolumn{2}{|c|}{ Beri tanda $(\sqrt{ })$ pada kolom yang sesuai dan isi pertanyaan } \\
\hline $\begin{array}{l}\text { Pembuatan } \\
\text { Perakitan Tulangan } \\
\text { Pembuatan Beton }\end{array}$ & $\begin{array}{ll}\sqrt[V]{ } \square \text { Dengan perencana } & \square \text { Tanpa perencana } \\
V \square \text { Manual } & \square \text { Mesin } \\
V_{\square} \text { Manual } & \square \text { Molen } \square \text { Ready Mix }\end{array}$ \\
\hline
\end{tabular}

\begin{tabular}{|c|c|c|c|c|c|}
\hline NO & & PENGAMATAN & YA & TIDAK & KURANG \\
\hline 1 & $\begin{array}{l}\text { GAMBAR } \\
\text { RENCANA }\end{array}$ & 1.Pembangunan berdasarkan gambar rencana & $\sqrt{ }$ & & \\
\hline \multirow{2}{*}{2} & \multirow{2}{*}{ DENAH } & 2. Denah simetris & J & & \\
\hline & & 3.Tidak ada tonjolan $>25 \%$ dari ukuran denah terbesar & & $\sqrt{2}$ & \\
\hline \multirow{5}{*}{3} & \multirow{5}{*}{ PONDASI } & 4. Kedalaman sesuai manual perancangan $(\min .60 \mathrm{~cm})$ & & j & \\
\hline & & 5. Lebar sesuai manual perancangan $(\min .60 \mathrm{~cm})$ & & J & \\
\hline & & 6. Tulangan kolom ditanamkan dalam pondasi sedalam 40 f atau lebih & & a & \\
\hline & & 7. Batu kali keras atau batu putih keras & J & & \\
\hline & & 8. Campuran mortar untuk spesi 1 pc : 4 psr & & & a \\
\hline \multirow{6}{*}{4} & \multirow{6}{*}{ SLOOF } & 9. Ukuran minimal sesuai manual perancangan $(\min .15 \mathrm{~cm} \times 20 \mathrm{~cm})$ & & $\mathrm{V}$ & \\
\hline & & 10. Tulangan memanjang sesuai manual perancangan $(\min 4 \mathrm{f} 10)$ & & J & \\
\hline & & 11. Tulangan begel sesuai manual perancangan $(\min \mathrm{f} 8-150)$ & & ป & \\
\hline & & 12. Ada angkur ke fondasi & & $\sqrt{ }$ & \\
\hline & & 13. Apakah beton sloof baik (tidak keropos) & & j & \\
\hline & & 14. Campuran beton $1 \mathrm{pc}: 2 \mathrm{psr}: 3 \mathrm{krl}$ & & $\mathrm{J}$ & \\
\hline \multirow{5}{*}{5} & \multirow{5}{*}{ KOLOM } & 15. Ukuran minimal sesuai manual perancangan $(\min .15 \mathrm{~cm} \times 15 \mathrm{~cm})$ & & J & \\
\hline & & 16. Tulangan memanjang sesuai manual perancangan $(\min 4 \mathrm{f} 10)$ & & 西 & \\
\hline & & 17. Tulangan begel sesuai manual perancangan ( $\min \mathrm{f8}-150)$ & & ป & \\
\hline & & 18. Apakah campuran beton kolom baik (tidak keropos) & & j & \\
\hline & & 19. Campuran beton $1 \mathrm{pc}: 2 \mathrm{psr}: 3 \mathrm{krl}$ & & 过 & \\
\hline \multirow{3}{*}{6} & \multirow{3}{*}{ DINDING } & $\begin{array}{l}\text { 20. Luas dinding yang dibatasi balok, sloof dan kolom tidak lebih dari } \\
9 \mathrm{~m} 2\end{array}$ & $\sqrt{ }$ & & \\
\hline & & 21. Ada angkur ke kolom & t & & \\
\hline & & 22. Campuran mortar untuk spesi 1 pc: 4 psr & 尚 & & \\
\hline \multirow{5}{*}{7} & \multirow{5}{*}{ RING BALOK } & 23. Ukuran minimal sesuai manual perancangan $(\min .12 \mathrm{~cm} \times 15 \mathrm{~cm})$ & & $\mathrm{T}$ & \\
\hline & & 24. Tulangan memanjang sesuai manual perancangan $(\min 4 \mathrm{f} 10)$ & & $\sqrt{ }$ & \\
\hline & & 25 . Tulangan begel sesuai manual perancangan ( $\min \mathrm{f8}-150)$ & & $\sqrt{ }$ & \\
\hline & & 26. Apakah campuran beton ring balk baik (tidak keropos) & & $\sqrt{ }$ & \\
\hline & & 27. Campuran beton $1 \mathrm{pc}: 2 \mathrm{psr}: 3 \mathrm{krl}$ & & $\sqrt{ }$ & \\
\hline 8 & $\begin{array}{l}\text { DETAIL } \\
\text { TULANGAN } \\
\text { PADA } \\
\text { PERTEMUAN } \\
\text { UJUNG BALOK } \\
\text { DAN KOLOM }\end{array}$ & $\begin{array}{l}\text { 28. Tulangan pada sudut akhir diangkur dengan panjang } 40 \mathrm{f} \text { atau } 30 \mathrm{f} \\
\text { dengan kait. }\end{array}$ & & $\sqrt{ }$ & \\
\hline 9 & SAMBUNGAN & 29. Ada overlap (sambungan lewatan) $\min 40 \mathrm{f}$ & & J & \\
\hline \multirow{5}{*}{10} & \multirow{5}{*}{$\begin{array}{l}\text { KUDA-KUDA } \\
\text { (dari Kayu) }\end{array}$} & 30. Ukuran kayu minimal $6 \mathrm{~cm} \times 12 \mathrm{~cm}$ & & & $\sqrt{ }$ \\
\hline & & 31. Sambungan diberi plat begel & $\sqrt{ }$ & & \\
\hline & & 32. Ada ikatan angin. & j & & \\
\hline & & 33. Ada angkur pada dudukannya & a & & \\
\hline & & 34. Kayu berwama gelap & 过 & & \\
\hline
\end{tabular}

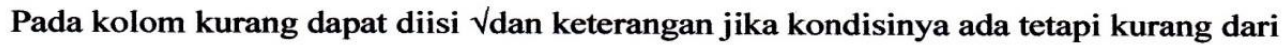
persyaratan minimum. Jika tidak tahu berarti "TIDAK".

Jumlah jawaban "YA" $=10 \times 1.0=10$

Jumlah jawaban "KURANG" $=2 \times 0.5=1$

Jumlah nilai $=11$

Skor Bangunan $=11 / 34 \times 100 \%=32,35 \%$ 


\section{Jurnal Rancang Bangun 2(2)37-44 2017}

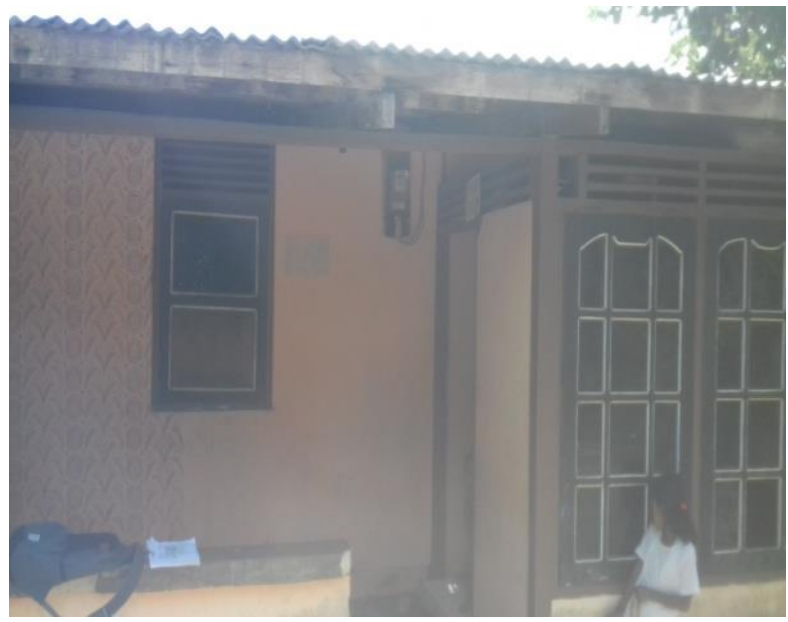

Gambar 2. Rumah Salah Satu Warga Di

\section{Pulau Doom}

Dari hasil penilaian dengan menggunakan formulir evaluasi bangunan sederhana (tipikal tembokan) yang diadopsi dari FEMA (Federal Emergency Management Agency) yang telah dimodifikasi oleh Iman Satyarno (Satyarno, 2012) yang di dalamnya telah disesuaikan dengan kondisi bangunan di Indonesia, maka dapat disimpulkan nilai dari masing masing elemen struktur bangunan seperti ;

1. Gambar Rencana

Jumlah jawaban "YA" $\quad=9 \times 1.0=$ 9

$\underline{\text { Jumlah jawaban "KURANG" }=0 \quad X \quad 0.5}$ $=0$

Jumlah nilai $=9$

Skor Bangunan $=9 / 52 \times 100 \%=17,31 \%$

2. Denah

Jumlah jawaban "YA" $\quad=101$ X $1.0=$ 101

$\underline{\text { Jumlah jawaban "KURANG" }=0 \quad \text { X } 0.5}$ $=0$

Jumlah nilai $=101$

Skor Bangunan $=101 / 104 \times 100 \%=$ $97,12 \%$

3. Pondasi

Jumlah jawaban "YA" = 176 X $1.0=$ 176

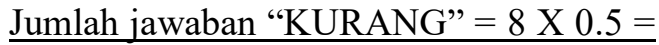

$\underline{4}$

Jumlah nilai $=180$

Skor Bangunan $=180 / 260 \times 100 \%=$ $69,23 \%$

4. Sloof

Jumlah jawaban "YA" $\quad=0 \times 1.0=0$

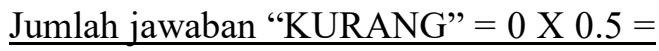
$\underline{0}$

Jumlah nilai $=0$

Skor Bangunan $=0 / 312 \times 100 \%=0 \%$

5. Kolom

Jumlah jawaban "YA" $\quad=0 \times 1.0=0$

Jumlah jawaban "KURANG" $=0 \times 0.5=$ $\underline{0}$

Jumlah nilai $=0$

Skor Bangunan $=0 / 260 \times 100 \%=0 \%$

6. Dinding

Jumlah jawaban "YA" $\quad=156$ X $1.0=$ 156

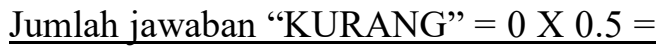
$\underline{0}$

Jumlah nilai $=156$

Skor Bangunan $=156 / 156 \times 100 \%=$ $100 \%$

7. Ring Balok

Jumlah jawaban "YA" $\quad=0 \times 1.0=0$

Jumlah jawaban "KURANG" $=0 \times 0.5=$ $\underline{0}$

Jumlah nilai $=0$

Skor Bangunan $=0 / 260 \times 100 \%=0 \%$

8. Detail Tulangan Pada Pertemuan Ujung

Balok dan Kolom

Jumlah jawaban "YA" $\quad=0 \times 1.0=0$

Jumlah jawaban "KURANG" $=0 \times 0.5=$

$\underline{0}$

Jumlah nilai $=0$

Skor Bangunan $=0 / 52 \times 100 \%=0 \%$

9. Sambungan

Jumlah jawaban "YA" $\quad=0 \times 1.0=0$

Jumlah jawaban "KURANG" $=0 \times 0.5=$ $\underline{0}$

Jumlah nilai $=0$

Skor Bangunan $=0 / 52 \times 100 \%=0 \%$

10. Kuda - Kuda 
Jumlah jawaban "YA" $\quad=164$ X 1.0

$=164$

Jumlah jawaban "KURANG" $=47$ X 0.5 $=23,5$

Jumlah nilai $=187,5$

Skor Bangunan $=187,5 / 260 \times 100 \%=$ $71,92 \%$

- Presentase Evaluasi Bangunan Sederhana Pulau Doom

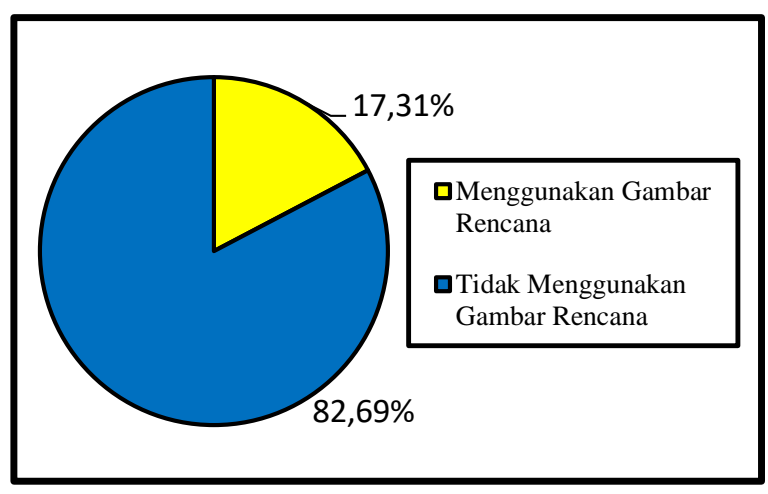

Gambar 2. Presentase Evaluasi Bangunan Sederhana (Tipikal Tembokan) untuk penggunaan Gambar Rencana Bangunan pada Pulau Doom

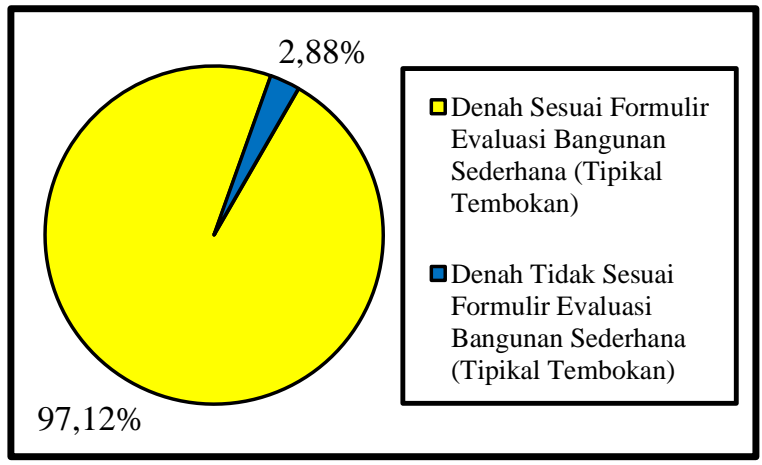

Gambar 3. Presentase Evaluasi Bangunan

Sederhana (Tipikal Tembokan) untuk penggunaan Denah Bangunan pada Pulau Doom

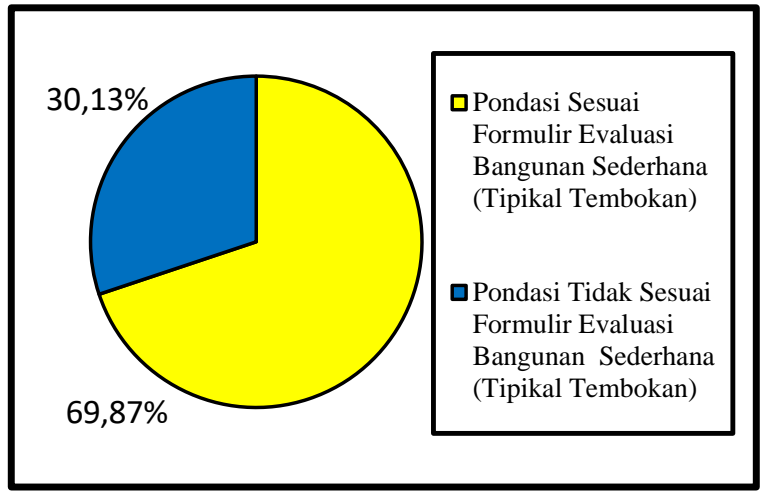

Gambar 4. Presentase Evaluasi Bangunan

Sederhana (Tipikal Tembokan) untuk penggunaan Pondasi Bangunan pada Pulau Doom

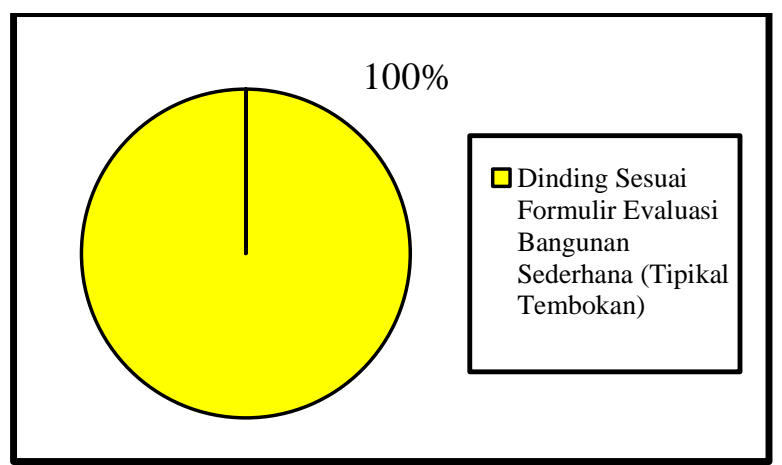

Gambar 5. Presentase Evaluasi Bangunan

Sederhana (Tipikal Tembokan) untuk penggunaan Dinding Bangunan pada Pulau Doom

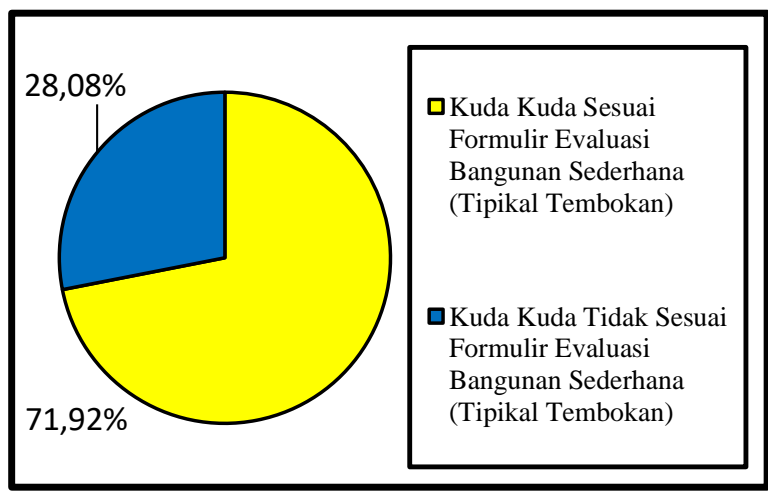

Gambar 6. Presentase Evaluasi Bangunan Sederhana (Tipikal Tembokan) untuk penggunaan Kuda Kuda Bangunan pada Pulau Doom

Sesuai dengan hasil dari evaluasi dengan menggunakan formulir evaluasi bangunan sederhana (tipikal tembokan), yang 
diadopsi dari FEMA (Federal Emergency Management Agency) yang telah dimodifikasi oleh Iman Satyarno (Satyarno, 2012) yang di dalamnya telah disesuaikan dengan kondisi bangunan di Indonesia maka dapat diperoleh presentase diPulau Doom adalah pelaksanaan struktur bangunan rumah pada elemen struktur pondasi $69,23 \%$, sloof $0 \%$, kolom $0 \%$, dinding $100 \%$, ring balok $0 \%$, detail tulangan pada pertemuan ujung kolom dan balok $0 \%$, sambungan $0 \%$, denah $97,12 \%$, gambar rencana $17,31 \%$, kuda-kuda $71,92 \%$ dan gunung-gunung $0 \%$.

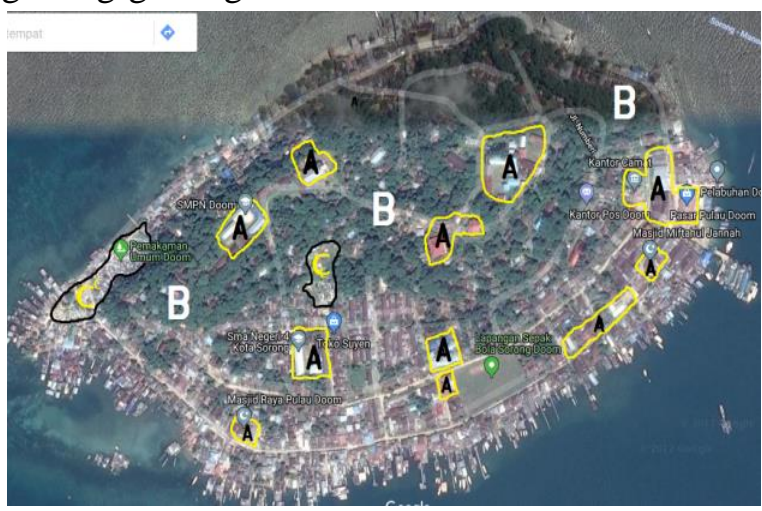

Gambar 7. Peta Lokasi Mitigasi Pulau Doom Keterangan ;

A. Daerah yang sebagian besar bangunannya sudah memenuhi standar bangunan tahan gempa

B. Daerah yang sebagian besar bangunannya belum memenuhi standar bangunan tahan gempa

C. Daerah pemakaman umum Pulau Doom

Bangunan rumah tinggal masyarakat Pulau Doom masih jauh dari standar bangunan tahan gempa dikarenakan masih belum memperhatikan kelayakan struktur untuk bangunan rumah tahan gempa. Banyak elemen-elemen penting sebagai penahan gaya gempa yang belum diterapkan pada bangunan masyarakat untuk tipikal tembokan sederhana. Kebanyakan kelemahan yang ada pada bangunan masyarakat Pulau Doom adalah pada sturktur utama, seperti sloof, kolom dan ring balok. Untuk struktur sloof, kolom dan ring balok, masyarakat pada Pulau Doom masih menggunakan struktur kayu dibanding tulangan, itu karena masyarakat beranggapan lebih ekonomis menggunakan kayu dari pada tulangan karena tidak membutukan material lebih banyak untuk pengecoran sloof, kolom dan ring balok nantinya. Hampir semua bangunan rumah warga tidak memiliki sloof, sehingga ikatan yang memastikan bahwa struktur akan bergerak secara bersamaan jika terjadi goyangan gempa tidak bekerja dengan baik, dindingnyapun banyak yang tidak diplester atau hanya diplester di salah satu sisi saja baik itu didalam atau diluar rumah. Padahal plesteran mampu untuk menahan dinding dari kegagalan lentur ke luar bidang dinding jika terjadi goyangan gempa. Oleh sebab itu hal-hal tersebut menyebabkan resiko bangunan rumah tinggal masyarakat di Pulau Doom sangat tinggi tingkat kerusakanya terhadap bencana gempa bumi.

\section{PENUTUP}

Berdasarkan hasil penelitian ini, serta pembahasan dan analisis yang telah dijabarkan sebelumnya, serta mengacuh pada formulir evaluasi bangunan sederhana (tipikal tembokan), yang diadopsi dari FEMA (Federal Emergency Management Agency) yang telah dimodifikasi oleh Iman Satyarno (Satyarno, 2012) dapat disimpulkan bahwa :

1. Bangunan rumah pada Pulau Doom dapat dikatakan bahwa sebagian besar belum memenuhi persyaratan yang telah ditentukan dalam persyaratan teknis bangunan tahan gempa. Bagian penting unsur penahan gaya gempa belum diterapkan pada bangunan masyarakat untuk tipikal tembokan sederhana. Struktur-struktur utama, seperti sloof, kolom dan ring balok kurang menjadi perhatian penting masyarakat, sehingga mereka hanya menggunakan struktur 
kayu di banding tulangan, dan banyak rumah yang tidak memiliki sloof.

2. Hasil analisis deskriptif data menunjukkan presentase di Pulau Doom yaitu pelaksanaan struktur bangunan rumah pada elemen struktur pondasi $69,23 \%$, sloof $0 \%$, kolom $0 \%$, dinding $100 \%$, ring balok $0 \%$, detail tulangan pada pertemuan ujung kolom dan balok $0 \%$, sambungan $0 \%$, denah $69,87 \%$, kuda-kuda $71,92 \%$ dan gunung-gunung $0 \%$.

3. Berikut alasan kenapa rumah tinggal sederhana yang telah diteliti masih banyak yang masuk kategori kurang sesuai dan tidak sesuai:

a. Kurangnya sosialisasi pemerintah terhadap bangunan rumah tinggal sederhana tahan gempa yang sesuai pedoman teknis rumah dan bangunan gedung tahan gempa, sehingga banyak masyarakat yang tidak mengetahuinya.

b. Kurangnya sosialisasi pemerintah terhadap bangunan rumah tinggal sederhana tahan gempa yang sesuai pedoman teknis rumah dan bangunan gedung tahan gempa, khususnya kepada tenaga ahli bangunan, dan,

c. Kebanyakan masyarakat membangun secara spontan, berdasarkan kebiasaan setempat, terkendala hal biaya serta waktu, dan pelaksanaanya mengikuti cara-cara masa lalu.

\section{REFERENSI}

DetikNews - Gempa 6,8 SR Guncang Sorong, Papua Barat (news.detik.com/berita/.../gempa-68sr-guncang-sorong-papua-barat diakses tanggal 21 Mei 2017)

Republik Indonesia. 2008. __, Peraturan Kepala Badan Penanggulangan Bencana Nomor 04 tahun 2008 tentang Pedoman Penyusunan Rencana Penanggulangan Bencana. Satyarno, Iman. 2012. Evaluasi Rehabilitasi dan Rekonstruksi Struktur. UGM. Yogyakarta.

Tanzil, 2014. Pulau Doom Papua Barat (http://www.pasirpantai.com/papua/ pulau-doom-sorong papua/ tanggal 21 Mei 2017)

UU RI Nomor 24 Tahun 2007 Tentang Penanggulangan Bencana 